\title{
Cereal-pea intercrops to improve sustainability in bioethanol production
}

\author{
Antonio Pellicanò • Maurizio Romeo • Aurelio Pristeri • \\ Giovanni Preiti • Michele Monti
}

Accepted: 25 January 2015 / Published online: 27 February 2015

(C) INRA and Springer-Verlag France 2015

\begin{abstract}
The environmental performance of secondgeneration biofuels from lignocellulosic biomass, such as crop residues, is foreseen to be superior to that of first-generation biofuels such as maize bioethanol. Moreover, using a legume as an intercrop can reduce costly $\mathrm{N}$ fertilizers inputs and can increase the $\mathrm{N}$ content of the straw mixture. Therefore, we studied cereal-legume intercrops as a source of food grain and straw bioethanol. We grew field pea and four cultivars of durum wheat, triticale, oat, and barley. Crops were grown during 2 years as a sole crop, in additive intercrop with $100 \%$ of the sole crop density for the cereal and $50 \%$ of sole crop density for the legume, and in replacement intercrop with $50 \%$ of the sole crop density for each crop. Tall cereal cultivars were preferred over shorter cereals for an extra production of straw. Results show that growth resources were used up to $23-26 \%$ more efficiently in intercrop than in sole crop for grain and straw production. Tall cereal cultivars suppressed legume yields in intercrops, thus reducing potential intercrop advantages. Pea in intercrop increased straw mixture $\mathrm{N}$ by $54 \%$ the first year and by $91 \%$ the second year, versus cereal alone.
\end{abstract}

Keyword Biofuels · Cereal-legume intercropping · Crop residues $\cdot$ Cereal straw $\cdot$ Pea $\cdot$ LER

\section{Introduction}

Due to the limitations of first-generation biofuels that are produced from simple sugars and starch (e.g., from sugar cane

\footnotetext{
A. Pellicanò $(\bowtie) \cdot M$. Romeo $•$ A. Pristeri $\cdot$ G. Preiti $\cdot$ M. Monti Department of Agriculture, University Mediterranea of Reggio Calabria, Loc. Feo di Vito, 89122 Reggio, Calabria, Italy

e-mail: antonio.pellicano@unirc.it
}

and sugar beet), greater emphasis has been placed on secondgeneration biofuels produced from lignocellulosic biomass. The development of second-generation biofuels is essential for a long-term future of biofuels. Their environmental performance is foreseen to be superior to that of first-generation biofuels in terms of greenhouse gas emissions from the production chain, broadness of the feedstock, and biofuel yields per hectare (Faaij 2010). Moreover, second-generation biofuels can offer better land use opportunities, including production on marginal lands and reduce competition with food crops (Sims et al. 2010). Employing less intensive and more sustainable crop production practices and using agricultural wastes and residues can increase the resource use efficiency and the environmental performance of biofuels (Hill 2007). Among lignocellulosic biomass sources, cereal straw has gained interest for bioethanol production (Petersson et al. 2007).

Intercropping - described as the simultaneous cultivation of two or more species on the same area of land (Vandermeer 1989) - is reported to bring several advantages versus monocrop systems including better land use efficiency, maintenance of soil fertility, and reduction of disease and pest incidence (Lithourgidis et al. 2011a). Due to their ability to fix nitrogen $(\mathrm{N})$ biologically from the atmosphere, legumes can be beneficial to the associated cereal crops and allow for a reduction of $\mathrm{N}$ fertilizer inputs into the system (Liu et al. 2011). Legume straw is rich in $\mathrm{N}$, and by mixing cereal and legume straw, the $\mathrm{N}$ content of the mixture can be increased. $\mathrm{N}$ sources are required during the fermentation process, and straw with a high $\mathrm{N}$ content can reduce the amount of synthetic $\mathrm{N}$ sources (e.g., urea) usually added in the fermentation media. Consequently, the energetic, environmental, and economic cost of the biofuels manufacturing process is reduced. Thomsen and Hauggaard-Nielsen (2008) studied the utilization of intercrop of clover-grass (Trifolium repens and Lolium perenne) under sown in a traditional wheat crop as a source of 
wheat grain for human/animal feed and mixed biomass for bioethanol production. Their results showed that supplementing wheat straw with clover-grass biomass had a positive effect on ethanol yields. Suitable lignocellulosic biomass for bioethanol production, along with high content of $\mathrm{N}$, should ideally also have a high content of cellulose and hemicellulose and low content of lignin since the latter creates technical challenges for the conversion of the sugars to ethanol (Petersson et al. 2007).

This study proposes cereal-pea intercrop systems as a bifunctional cropping system for cereal-legume mixed grain and straw production. The grain is anticipated to be used for human/animal feed and the straw mixture for bioethanol production. This can make optimal use of available farm land and secure the best possible resource use efficiency throughout the full bioenergy manufacturing chain. In this study, tall cereal cultivars were preferred over the medium/short ones in order to increase the quantity of straw and hence reduce the grain/ straw ratio. It is known that in an arable cropping system, systematic straw removal can cause soil quality-related issues, i.e., soil erosion and depletion of soil organic matter pool (Blanco-Canqui and Lal 2009). The extra production of straw can be alternatively left or incorporated in the soil to preserve its fertility.

Wheat, triticale, oat, and barley were intercropped with field pea with the aim to assess the intercrop yields and productive advantages versus cereal sole crops (Fig. 1). To our knowledge, information on quality of cereal-legume intercrop straw harvested at full ripening stage of the crop has not been previously reported, while much research has been done on grain and biomass quality (forage/ensilage use) (Lithourgidis et al. 2011a; Reddy et al. 2003). A further aim was therefore to assess the quality of the straw mixture- $\mathrm{N}$ content and fiber composition - and the improvement that the legume could make in terms of $\mathrm{N}$ content compared to cereal sole crop residues.

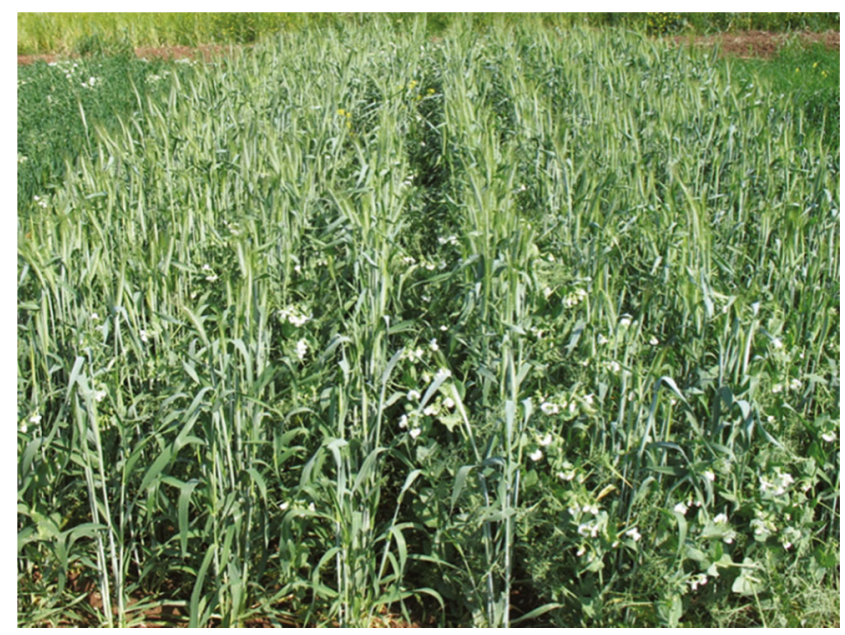

Fig. 1 Row by row intercropping of Triticale (Triticum $\times$ Secale $)$ and pea (Pisum sativum)

\section{Materials and methods}

\subsection{Experimental site}

The experiment was carried out over two growing seasons (2006/2007 and 2007/2008) on an experimental field at the University Mediterranea of Reggio Calabria, Italy $\left(38^{\circ} 10^{\prime} \mathrm{N}\right.$, $15^{\circ} 45^{\prime}$ E, $232 \mathrm{~m}$ a.s.1.). The soil was a "TypicHaploxeralfs" (USDA) with the following physical-chemical characteristics (0-30 cm depth): $36 \%$ clay, $24 \%$ silt, and $40 \%$ sand, pH 7.15, organic matter content $1.95 \%$, total N (Kjeldahl) $1.12 \%$, P (Olsen) 12.31 ppm, and K 372.58 ppm.

Air temperature regimes were similar for the 2 years and in line with the 20-year mean of the experimental site. The mean of the monthly minimum temperature during the cropping season (period December-June) was 12 and $11^{\circ} \mathrm{C}$ respectively in 2006/2007 and 2007/2008. The mean of the monthly maximum temperature was 19 and $18{ }^{\circ} \mathrm{C}$ respectively in $2006 / 2007$ and 2007/2008. February in 2008 was colder than the previous year, and the minimum daily air temperature dropped to $4{ }^{\circ} \mathrm{C}$. In both years, air temperature started increasing constantly from March onwards. In contrast, large differences in rainfall between the first $(400 \mathrm{~mm})$ and second (226 mm) cropping seasons were recorded (20-year mean of the total rainfall of the period December-June is $394 \mathrm{~mm}$ ). During the first year, precipitation was mainly distributed between December and March (323 mm). March in 2007 was particularly rainy and it was followed by a sharp increase in the air temperature in April. In the second year, rainfall was mostly concentrated in October and November before sowing $(266 \mathrm{~mm})$, and the crops received much less rainfall afterward compared to the previous year.

\subsection{Treatments and experimental design}

A leafless, medium early, and indeterminate growth pea (P) (Pisum sativum) cv. Hardy was grown in binary row intercrops (IC) with durum wheat (W) (Triticum turgidum spp. durum) cv. Valbelice, with Triticale $(\mathrm{T})($ Triticum $\times$ Secale) cv. Trica, with oat $(\mathrm{O})$ (Avena sativa) $\mathrm{cv}$. Argentina, and with barley (B) (Hordeum vulgare) cv. Gotic. Due to the height of the cereal cultivars chosen in this study, we adopted a tall, indeterminate growth pea cultivar able to grow into the upper levels of the cereal canopy and better compete for light than shorter and determinate growth cultivars. Pea was preferred to faba bean (Vicia faba L. sub. minor) because in previous studies in a similar environment in Southern Italy (Gooding et al. 2007), a leafless pea cultivar performed better than faba bean in intercrop with the latter causing reduction in cereal yields. Sole crop (SC) treatments (WSC, BSC, OSC, TSC, PSC) were sown at the recommended seed density of 90 seeds $\mathrm{m}^{-2}$ for pea, 300 seeds $\mathrm{m}^{-2}$ for oat and barley and 400 seeds $\mathrm{m}^{-2}$ for wheat and triticale. Intercrop treatments were 
established according to a replacement and additive design. In the replacement design (W50P50, B50P50, T50P50, O50P50), the two components were sown at half the density used in the respective sole crops, in a way that one component replaced a proportion of the other maintaining a constant total density according to the recommended sole crop density. In the additive design (W100P50, B100P50, T100P50, O100P50), the cereal and pea were intercropped respectively at full and at half the density used for sole crop. One component was added to the other, so that the final plant population was more than the recommended/optimal density of the sole crops (De Wit and Van den Bergh 1965). A row spacing of $12.5 \mathrm{~cm}$ was adopted for both intercrop and sole crop treatments. The experimental design was a randomized complete block with 13 treatments replicated three times. Plot size was $21 \mathrm{~m}^{2}$.

\subsection{Crop management}

Barley was the preceding crop. The residual mineral $\mathrm{N}$ in the soil $(0-60 \mathrm{~cm})$ at sowing was $47.3 \pm 4.0$ and $35.3 \pm$ $3.13 \mathrm{~kg} \mathrm{ha}^{-1}$ respectively in the first and second cropping season. Eighty-four kilograms per hectare of $\mathrm{Ca}\left(\mathrm{H}_{2} \mathrm{PO}_{4}\right)_{2}$ (superphosphate) was incorporated into the soil at sowing. Crops were grown without $\mathrm{N}$ application. Intercrops and sole crops were sown using a double hopper plot line seeder on 18 December 2006 and 21 December 2007 in the first and second year, respectively. All crops were kept free of weeds by hand when necessary. Harvesting took place at pea physiological maturity for pea sole crop and at cereal physiological maturity (Zadoks 92) for both cereal sole crop and intercrop.

\subsection{Data collection and analysis}

Aboveground biomass was sampled at harvest ripeness of the latest maturing species. In both sole crop and intercrop treatments, plants from $1 \mathrm{~m}^{2}$ area were cut at the soil surface. In the intercrop treatments, cereal and pea were harvested separately. The biomass was then dried at $50{ }^{\circ} \mathrm{C}$ to constant weight to determine total dry matter production and then separated and threshed into straw and grain.

Straw samples were ground in a laboratory mill through a 1-mm sieve. These were analyzed in duplicate for total $\mathrm{N}$ and crude fiber content. Total $\mathrm{N}$ content was determined using the Kjeldahl method. Acid detergent fiber (ADF), neutral detergent fiber (NDF), and acid detergent lignin (ADL) were analyzed as described by Goering and Van Soest (1970). Cellulose and hemicellulose were calculated from the ADF and NDF data.

\subsection{Calculation and statistics}

The advantage of intercropping compared to sole cropping was assessed using the Land Equivalent Ratio (LER). LER is one of the most common ways of assessing yield advantages of intercrops over sole crops. It is defined as the relative land area under sole crops that is required to produce the same yield achieved by intercropping (Vandermeer 1989). LER for a cereal-pea intercrop was calculated on the basis of the total harvested dry matter and as the sum of partial LER values for cereal $\left(L_{\mathrm{C}}\right)$ and pea $\left(L_{\mathrm{P}}\right)$ in accordance with De Wit and Van den Bergh (1965):

$L_{C}=\frac{Y_{\mathrm{C}-\mathrm{IC}}}{Y_{\mathrm{C}-\mathrm{SC}}} ; \quad L_{P}=\frac{Y_{\mathrm{P}-\mathrm{IC}}}{Y_{\mathrm{P}-\mathrm{SC}}} ; \quad \mathrm{LER}=L_{C}+L_{P}$

$Y_{\mathrm{C}-\mathrm{IC}}$ and $Y_{\mathrm{P}-\mathrm{IC}}$ are the yield of the cereal and pea component in IC, respectively, and $Y_{\mathrm{C}-\mathrm{SC}}$ and $Y_{\mathrm{P}-\mathrm{SC}}$ are the yield of the cereal and pea component in SC, respectively. LER values greater than 1 indicate an advantage of intercropping over monoculture.

The competitive relationship between the two components of intercrop was determined using the Aggressivity value (A) proposed by McGilchrist and Trenbath (1971) as follows:

$$
\begin{aligned}
& \text { Aggressivity of cereal }\left(A_{c}\right)=\frac{Y_{\mathrm{C}-\mathrm{IC}}}{Y_{\mathrm{C}-\mathrm{SC}} \times Z_{\mathrm{c}}}-\frac{Y_{\mathrm{P}-\mathrm{IC}}}{Y_{\mathrm{P}-\mathrm{SC}} \times Z_{\mathrm{p}}} \\
& \text { Aggressivity of pea }\left(A_{p}\right)=\frac{Y_{\mathrm{P}-\mathrm{IC}}}{Y_{\mathrm{P}-\mathrm{SC}} \times Z_{\mathrm{p}}}-\frac{Y_{\mathrm{C}-\mathrm{IC}}}{Y_{\mathrm{C}-\mathrm{SC}} \times Z_{\mathrm{c}}}
\end{aligned}
$$

where $Y_{\mathrm{C}-\mathrm{IC}}, Y_{\mathrm{C}-\mathrm{SC}}, Y_{\mathrm{P}-\mathrm{IC}}$, and $Y_{\mathrm{P}-\mathrm{SC}}$ are the same as above, and $Z_{\mathrm{c}}$ and $Z_{\mathrm{p}}$ are the sown proportion for intercrop relative to the sole crops of cereal and pea, respectively.

Aggressivity provides a simple measure of how much the relative yield increase of one component is greater than that of the other component. A value of zero indicates that the component species are equally competitive. For any other situation, both components will have the same numerical value with a positive sign for the dominant component and negative for the dominated. The greater the numerical value, the bigger the difference in competitive ability between the two components.

Analysis of variance for randomized crossing block design (RCBD) over 2 years was performed using the SYSTAT 11.0 software (SYSTAT Software Inc., Erkrath, D). The analysis included eight intercrops (combination between cultivar and intercrop design) and four sole crop treatments. Pea sole crop was not included in the statistical analysis. When a significant interaction year $\times$ treatment was found, the analysis for a single year was carried out. If the analysis of variance showed significant treatment effects, a least significant difference 
(LSD) test was used to compare treatment means $(P=0.05)$. Because we intercropped tall cereal cultivars with pea, the height gap between the two components observed during the two cropping seasons might have increased competition for light and negatively affected legume yields. A correlation analysis was therefore performed plotting cereal plant height (independent variable) against pea biomass (dependent variable).

\section{Results and discussion}

3.1 Biomass yields and competition between components in intercrop

ANOVA for biomass, grain, and straw yields indicated treatment by growing season interactions. Thus, yield values of the two growing seasons are shown and discussed separately in Fig. 2. The actual plant densities were within $20 \%$ of the target densities for pea and cereal plants per square meters independent of the year (data not shown). The different environmental conditions between the two cropping seasons significantly affected cereal and pea biomass yields $(P \leq 0.001)$.

The average cereal biomass yield was greater in the year with higher rainfall (11.9 and $9.6 \mathrm{t} \mathrm{ha}^{-1}$ in 2006/2007 and $2007 / 2008$, respectively). This effect was particularly noticeable in wheat where the yield decreased by $46 \%$ from the first to second year. The yield decrement for the other cereals was not as marked as in wheat ranging from $13 \%$ (oat) to $21 \%$ (barley). The drought conditions of the second year affected the cereals grown in intercrop more than in sole crop $(-2.88$ and $-1.12 \mathrm{tha}^{-1}$, respectively from the first to the second year).

The cereal was the dominant component in all the intercrops and in both cropping seasons as shown by the values of aggressivity (Table 1). This was also reported by Banik et al. (2006) and Hauggaard-Nielsen and Jensen (2001). In both cropping seasons, pea biomass yields in intercrop were lower than the expected ones according to the sowing density, particularly in 2006/2007 when the cereal was more aggressive than in 2007/2008 with a stronger negative impact on pea biomass yield. In 2007/2008, changes in the competitive strength of the pea and barley intercrop components had a marked effect on the proportion of the pea biomass. In contrast to the decrement of the cereal biomass yields, the pea biomass increased by more than 1.5 times compared to the previous year. Pea sole crop yields were similar in 2006/2007 and 2007/2008 (6.45 and $6.06 \mathrm{t} \mathrm{ha}^{-1}$, respectively). Low pea biomass yields may reduce the aforementioned advantages of the intercrop versus sole crop systems and, specific to this study, may not bring any advantage to the transformation process for the biofuel production due to the low pea proportion in the harvested straw mixture.
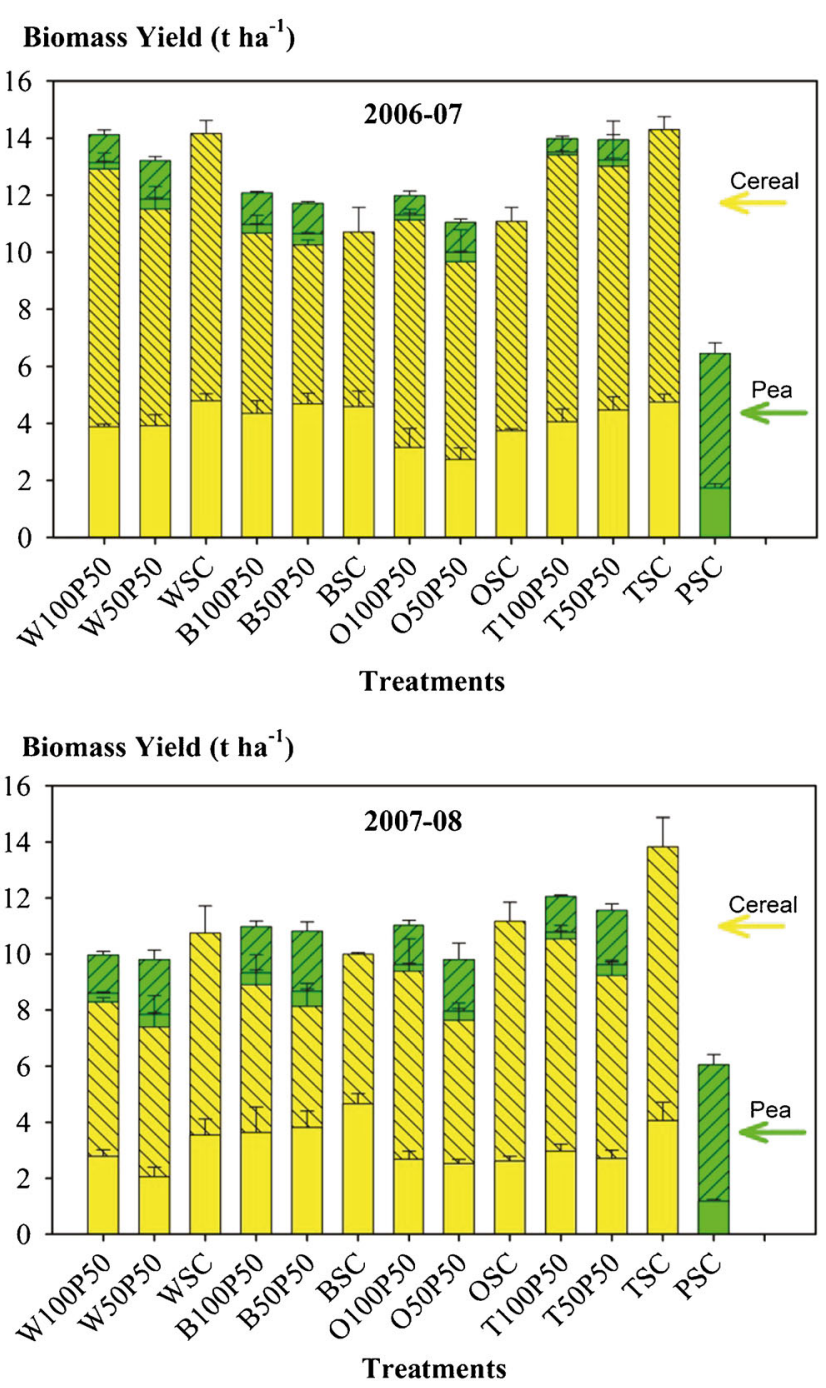

Fig. 2 Biomass production and partitioning in grain (plain) and straw (coarse) of pea and cereals grown in additive and replacement intercrops as well as sole crop (SC) during the two cropping seasons. Note the lower proportion of pea biomass in the intercrops compared to the expected one according to the density. $W$ wheat, $B$ barley, $O$ oat, $T$ triticale, $P$ pea. Additive intercrop (i.e., W100P50) $=100 \%$ of the sole crop density for the cereal and $50 \%$ of sole crop density for the legume. Replacement intercrop (i.e., W50P50) $=50 \%$ of the sole crop density for each crop. Values are the mean $(n=3) \pm$ S.E. $\operatorname{LSD}_{0.05}$ for cereal biomass $=1.23$ in $2006 / 2007$ and 1.78 in $2007 / 2008 ;$ LSD $_{0.05}$ for pea biomass $=0.15$ in $2006 / 2007$ and 0.49 in 2007/2008

In 2006/2007, cereal plant height ranged between $74.5 \mathrm{~cm}$ (barley) and $111.4 \mathrm{~cm}$ (wheat), while in 2007/2008, it ranged between $61.9 \mathrm{~cm}$ (barley) and $85 \mathrm{~cm}$ (triticale) (data not shown). Pea plant height was on average across all treatments 74 and $60 \mathrm{~cm}$ in 2006/2007 and 2007/2008, respectively (data not shown). We observed a tendency for pea biomass yield to decrease as cereal plant height increased, and this was confirmed in $2006 / 2007$ by the significant regression $(P \leq 0.05)$ between cereal plant height and pea biomass yields as illustrated in Fig. 3. In 2007/2008, pea plants could grow into the upper levels of the cereal canopy compared to the previous 
Table 1 Partial and total Land Equivalent Ratio (LER) calculated for cereal, pea grain, and straw yields over 2 years and Aggressivity Index (AI) calculated on annual biomass yields of additive and replacement intercrops

\begin{tabular}{|c|c|c|c|c|c|c|c|c|}
\hline \multirow[t]{2}{*}{ Treatments } & \multirow[b]{2}{*}{ Cereal } & \multicolumn{2}{|l|}{ LER grain } & \multicolumn{3}{|c|}{ LER straw } & \multirow{2}{*}{$\begin{array}{l}\text { AI } \\
2006 / 2007 \\
\text { Cereal }\end{array}$} & \multirow{2}{*}{$\begin{array}{l}\text { AI } \\
2007 / 2008 \\
\text { Cereal }\end{array}$} \\
\hline & & Pea & Total & Cereal & Pea & Total & & \\
\hline W100P50 & 0.76 & 0.16 & 0.92 & 0.87 & 0.20 & 1.07 & 0.70 & 0.24 \\
\hline W50P50 & 0.66 & 0.26 & 0.92 & 0.78 & 0.28 & 1.06 & 1.33 & 0.55 \\
\hline B100P50 & 0.86 & 0.23 & 1.09 & 1.00 & 0.23 & 1.23 & 0.77 & 0.19 \\
\hline B50P50 & 0.92 & 0.34 & 1.26 & 0.86 & 0.34 & 1.20 & 1.49 & 0.70 \\
\hline O100P50 & 0.93 & 0.14 & 1.07 & 0.93 & 0.21 & 1.14 & 0.75 & 0.29 \\
\hline O50P50 & 0.85 & 0.23 & 1.08 & 0.76 & 0.31 & 1.07 & 1.30 & 0.61 \\
\hline T100P50 & 0.80 & 0.12 & 0.92 & 0.88 & 0.18 & 1.06 & 0.76 & 0.30 \\
\hline Т50P50 & 0.81 & 0.22 & 1.03 & 0.78 & 0.27 & 1.05 & 1.54 & 0.61 \\
\hline $\mathrm{LSD}_{0.05}$ & 0.16 & 0.10 & 0.21 & 0.14 & 0.08 & 0.14 & & \\
\hline Mean06/07 & $0.85 \mathrm{a}$ & $0.12 \mathrm{~b}$ & $0.97 \mathrm{~b}$ & $0.95 \mathrm{a}$ & $0.15 \mathrm{~b}$ & $1.10 \mathrm{a}$ & & \\
\hline Mean07/08 & $0.80 \mathrm{a}$ & $0.30 \mathrm{a}$ & $1.10 \mathrm{a}$ & $0.77 \mathrm{~b}$ & $0.35 \mathrm{a}$ & $1.12 \mathrm{a}$ & & \\
\hline YearxIC & $*$ & NS & NS & NS & NS & NS & & \\
\hline
\end{tabular}

Plant growth resources were used more efficiently in intercrop than in sole crop; however, grain total LER was less than 1 indicating that there was not always complementarity in the use of growth resources. Note the decrement of the Aggressivity of the cereals during intercrop from 2006/2007 to $2007 / 2008$. Additive intercrop (i.e., W100P50) $=100 \%$ of the sole crop density for the cereal and $50 \%$ of sole crop density for the legume. Replacement intercrop (i.e., W50P50) $=50 \%$ of the sole crop density for each crop. Values are the mean ( $n=6$ for LER and $n=3$ for AI). Different letters for annual means indicate significant differences at $P \leq 0.05$

$W$ wheat, $B$ barley, $O$ oat, $T$ triticale, $P$ pea, $\underline{N S}$ not significant

* Significant at $P \leq 0.05$

year and potentially gain better access to higher light levels. Competition for the light resource is reported by HauggaardNielsen and Jensen (2001) for cereal-pea intercrops. According to Fujita et al. (1992), shading of the legume component in intercrop can affect photosynthesis and $\mathrm{N}_{2}$

\section{Pea biomass yield $\left(\mathrm{t} \mathrm{ha}^{-1}\right)$}

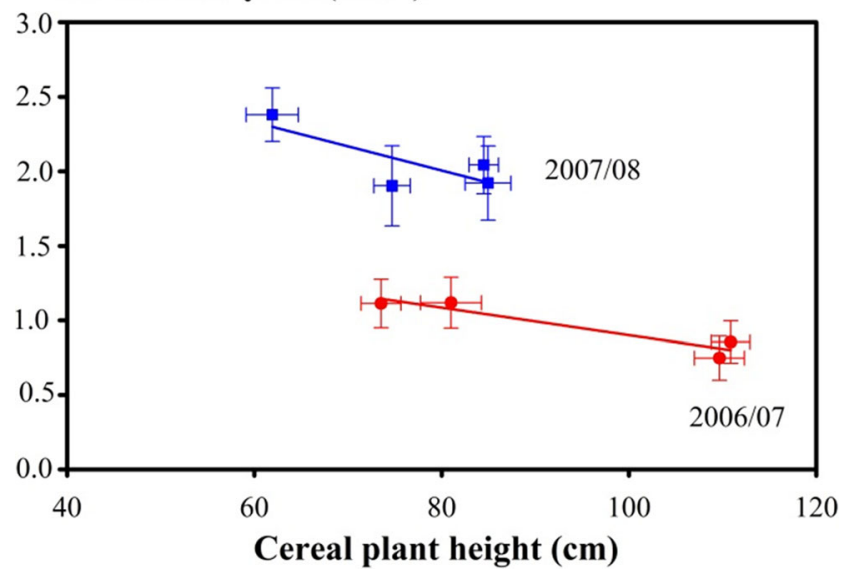

Fig. 3 Correlation between cereal plant height and pea biomass yield for intercrop in 2006/2007 and 2007/2008. The correlation shows a tendency for pea biomass yield to decrease as cereal plant height increased probably due to competition for the light between the two components of intercrop. Values are the mean $(n=6)$ of the additive $(100 \%$ of the sole crop density for the cereal and $50 \%$ of sole crop density for the legume) and replacement (50\% of the sole crop density for each crop) intercrop designs. $y=-0.0093 \mathrm{x}+1.8365\left(R^{2}=0.858 ; P=0.048\right) ; y=-0.0162 \mathrm{x}+$ $7.7571\left(R^{2}=0.477 ; P=0.206\right)$ respectively in $2006 / 2007$ and $2007 / 2008$ symbiotic fixation especially during later growth stages. Our results suggest that the tall cereal cultivars might have affected the pea's ability to intercept the light with negative consequences on its biomass yield, especially in the first cropping season when the height gap between the two intercrop components was bigger.

\subsection{Grain and straw yields}

ANOVA indicated significant differences among treatments in grain and straw yields in 2006/2007 and 2007/2008. In both cropping seasons (Fig. 2), cereal grain yields were on average higher for sole crops than in the additive $(+0.61$ and + $0.65 \mathrm{t} \mathrm{ha}^{-1}$ respectively in 2006/2007 and 2007/2008) and in the replacement intercrops $\left(+0.51\right.$ and $+0.73 \mathrm{tha}^{-1}$ respectively in 2006/2007 and 2007/2008). This was also observed in barley-faba (Agegnehu et al. 2006) and wheat-faba (Agegnehu et al. 2008) 100:50 additive intercrops. Cereal grain yields in intercrop were not affected by the design resulting similar in the additive and replacement intercrops. All cereals showed a high degree of plasticity in terms of grain yields when the sowing density was reduced by $50 \%$ in the replacement design. Due to the ability to tiller, cereals compensated for low initial densities as also reported by Neumann et al. (2009). Cereal straw yields were higher in sole crop than in intercrop $\left(+0.43\right.$ and $+1.92 \mathrm{tha}^{-1}$ respectively in 2006/2007 and 2007/2008). The additive overyielded the replacement 
intercrop $\left(+1.02\right.$ and $+0.94 \mathrm{t} \mathrm{ha}^{-1}$ respectively in 2006/2007 and 2007/2008). Differences between additive and replacement design were significant for wheat-pea and oat-pea intercrops in 2006/2007 and in triticale-pea in 2007/2008.

In contrast, pea was highly affected by the intercrop design as also reported by Agegnehu et al. (2006). For all the intercrops, on average, pea grain and straw yields were higher in replacement than in the additive design $(+0.15$ and + $0.13 \mathrm{t} \mathrm{ha}^{-1}$ respectively in 2006/2007 and in 2007/2008 for grain and +0.34 and $+0.54 \mathrm{tha}^{-1}$ respectively in 2006/2007 and in 2007/2008 for straw).

With regard to the total grain yield of the intercrop, significant differences between the two intercrop designs were observed for all intercrops and during both cropping seasons. Significant differences in total straw yield were observed for all intercrops in 2006/2007 while only in wheat-pea and triticale-pea intercrops in 2007/2008.

In this study, the harvested grain of cereal and pea intercrop is anticipated to be used either for human or animal feed. In both cases, the two components can be harvested simultaneously and (i) used as a mixture for animal feed or (ii) the cereal and pea grain can be separated and used for human consumption. When the grain is used as a mixture, even without any sort of weed control for the intercropping system, the contamination of the grain mixture by other species can be minimal. In the present study, all treatments were kept free of weeds during the cropping season, and the weed infestation of the harvested grain mixture was almost null and not comparable to the situation where no weed control was carried out. Nevertheless, in various growing West European conditions, pea-cereal intercrops exhibited high levels of weed suppression - even with a low percentage of cereal in the total biomass - and this was regardless of the particular weed infestation (species and productivity), crop biomass, or soil $\mathrm{N}$ availability (Corre-Hellou et al. 2011). When the intercrop grain is used for human consumption, the separation of the two species is technically possible and can be carried out in situ (farm). This operation can cause pea grain breakage which, however, does not compromise its use in the food industry.

\subsection{Land-use efficiency}

LER was calculated based on grain and straw yield. ANOVA indicated treatments by year interaction only for cereal grain partial LER $(P \leq 0.05)$. Means on the two growing seasons are shown in Table 1.

Plant growth resources were used up to 26 and $23 \%$ more efficiently than sole crop respectively for grain and straw production. All the intercrops showed straw total LER greater than 1 ranging from 1.05 to 1.23 . Grain total LER showed higher variability ranging from 0.92 to 1.26 . These values were in line with other studies carried out on cereal-legume intercrops (Agegnehu et al. 2008; Chu et al. 2004; Hauggaard-
Nielsen et al. 2006). Grain total LER less than 1 indicated that there was not always complementarity in the use of growth resources and that intraspecific and interspecific competition occurred between components.

The effect of the growing season was significant for grain total LER $(P \leq 0.05)$ but not for straw total LER. Grain total LER increased on average over the two seasons (from 0.97 to 1.10), and this suggests that a higher degree of complementarity in use of resources occurred in 2007/2008 for grain production. Less shading of pea in intercrop in 2007/2008 might have resulted in a better light resource use complementarity with positive effects on growth (higher total LERs). Considering the two components separately, cereal grain partial LER remained almost unvaried over the two seasons (from 0.85 to 0.80 on average across all treatments), whereas pea grain partial LER increased significantly $(P \leq 0.001)$ (from 0.12 to 0.30 ). The performance of the pea was therefore decisive for grain total LER values $>1$ as also reported by Rauber et al. (2001). Average straw total LER did not significantly differ between the two seasons (from 1.10 to 1.12). Due to a better performance of the legume component in 2007/2008, pea partial LER increased from 0.15 to 0.35 , but it was counterbalanced by a lower cereal partial LER (from 0.95 to 0.77).

Differences were not significant for grain total LER and straw total LER between the additive and the replacement design for all intercrops. This means that the advantages of the intercrops over the respective sole crops were irrespective of the design. Similar results were reported for an analogous environment in Pristeri et al. (2006) for wheat-faba additive (100:50) and replacement (50:50) intercrop. Among the treatments, B50P50 reported values higher than 1.20 for both grain and straw total LER showing a high level of land use efficiency versus sole crop for either grain or straw production.

\subsection{Intercrop straw quality}

Straw N content and fiber composition of cereals and pea grown in sole crops and intercrops are reported in Table 2 separately for the two growing seasons. Mixed crop residues from cereal-legume intercrops are reported to have higher $\mathrm{N}$ content than those of sole cereal crops due to the presence of the legume in the straw mixture (Hauggaard-Nielsen et al. 2003). Had this been the case in the present study, we would expect a higher $\mathrm{N}$ content in the straw mixture for all intercrops compared to that of their corresponding cereal sole crops. The pea proportion in the straw mixture increased on average from $9.16 \%$ in $2006 / 2007$ to $23.06 \%$ in $2007 / 2008$ due to the better performance of the legume in intercrop in the second cropping season as mentioned earlier. The average $\mathrm{N}$ content of the straw mixture followed a similar trend significantly increasing $(P \leq 0.01)$ from $0.48 \%$ in $2006 / 2007$ to $0.60 \%$ in $2007 / 2008$. 
Table 2 Straw composition (\%) of cereal and pea sole crops (SC) and straw mixture composition of additive and replacement intercrops in 2006/2007 and 2007/2008

\begin{tabular}{|c|c|c|c|c|c|c|c|c|c|c|}
\hline Treatments & PeaIC & Nitrogen & $\begin{array}{l}\text { 2006/2007 } \\
\text { Cellullose }\end{array}$ & Hemicellulose & Lignin & PeaIC & Nitrogen & $\begin{array}{l}\text { 2007/2008 } \\
\text { Cellullose }\end{array}$ & Hemicellulose & Lignin \\
\hline W100P50 & 6.0 & $0.34 \mathrm{bd}$ & $39.89 \mathrm{ac}$ & 27.81 & 6.63 & 19.8 & $0.50 \mathrm{~b}$ & $40.54 \mathrm{a}$ & $24.35 \mathrm{~cd}$ & $4.95 \mathrm{de}$ \\
\hline W50P50 & 9.6 & $0.35 \mathrm{bc}$ & $40.97 \mathrm{ac}$ & 25.65 be & $6.32 \mathrm{ac}$ & 26.9 & $0.57 \mathrm{ab}$ & 37.73 & $24.72 \mathrm{~cd}$ & $6.29 \mathrm{bc}$ \\
\hline WSC & - & $0.25 \mathrm{~d}$ & $39.96 \mathrm{ac}$ & $26.76 \mathrm{ad}$ & $7.97 \mathrm{a}$ & - & $0.25 \mathrm{e}$ & $38.88 \mathrm{ac}$ & $26.65 \mathrm{ac}$ & $5.93 \mathrm{bc}$ \\
\hline B100P50 & 8.3 & $0.42 \mathrm{~b}$ & $40.86 \mathrm{ac}$ & $25.41 \mathrm{ce}$ & $5.76 \mathrm{bc}$ & 23.8 & $0.80 \mathrm{a}$ & $39.73 \mathrm{ab}$ & $23.61 \mathrm{ed}$ & $4.87 \mathrm{de}$ \\
\hline B50P50 & 16.0 & 0.63 & $41.61 \mathrm{a}$ & $24.71 \mathrm{de}$ & $5.76 \mathrm{bc}$ & 33.2 & $0.80 \mathrm{a}$ & $37.01 \mathrm{ce}$ & $21.89 \mathrm{e}$ & $4.79 \mathrm{de}$ \\
\hline $\mathrm{BSC}$ & - & $0.31 \mathrm{bd}$ & $40.51 \mathrm{ac}$ & $28.35 \mathrm{a}$ & $6.70 \mathrm{ac}$ & - & $0.29 \mathrm{de}$ & 37.05 be & $29.46 \mathrm{a}$ & $4.39 \mathrm{e}$ \\
\hline O100Р50 & 7.8 & $0.64 \mathrm{a}$ & $38.17 \mathrm{~cd}$ & $24.72 \mathrm{de}$ & 5.73 & 17.3 & $0.55 \mathrm{ab}$ & $36.21 \mathrm{de}$ & $25.82 \mathrm{bd}$ & $7.43 \mathrm{a}$ \\
\hline O50P50 & 13.2 & $0.65 \mathrm{a}$ & $36.65 \mathrm{~d}$ & $24.41 \mathrm{e}$ & $6.91 \mathrm{ab}$ & 26.5 & $0.63 \mathrm{ab}$ & $38.34 \mathrm{ad}$ & $26.24 \mathrm{bd}$ & $4.56 \mathrm{e}$ \\
\hline OSC & - & $0.42 \mathrm{~b}$ & $38.50 \mathrm{bd}$ & $27.64 \mathrm{ac}$ & $5.05 \mathrm{c}$ & - & $0.40 \mathrm{bd}$ & $35.79 \mathrm{de}$ & $28.27 \mathrm{ab}$ & $3.57 \mathrm{f}$ \\
\hline T100P50 & 4.7 & $0.40 \mathrm{~b}$ & $40.57 \mathrm{ac}$ & 25.84 be & $5.91 \mathrm{bc}$ & 14.5 & $0.43 \mathrm{bc}$ & 38.17 ae & 26.19 & 5.29 \\
\hline Т50Р50 & 7.7 & $0.42 \mathrm{~b}$ & $41.35 \mathrm{a}$ & 25.43 be & $6.69 \mathrm{ac}$ & 22.6 & $0.55 \mathrm{ab}$ & $39.48 \mathrm{ab}$ & $25.15 \mathrm{~cd}$ & $4.51 \mathrm{e}$ \\
\hline TSC & - & $0.27 \mathrm{~cd}$ & $41.32 \mathrm{ab}$ & $26.56 \mathrm{ae}$ & $6.64 \mathrm{ac}$ & - & 0.32 ce & $39.16 \mathrm{ac}$ & $28.21 \mathrm{ab}$ & $5.32 \mathrm{~cd}$ \\
\hline Mean & & 0.43 & 40.03 & 26.11 & 6.34 & & 0.52 & 38.10 & 25.88 & 5.16 \\
\hline SE & & \pm 0.04 & \pm 0.44 & \pm 0.38 & \pm 0.22 & & \pm 0.05 & \pm 0.42 & \pm 0.62 & \pm 0.29 \\
\hline PSC & & 1.39 & 40.62 & 13.17 & 8.45 & & 1.44 & 33.90 & 13.82 & 5.90 \\
\hline
\end{tabular}

Note that for some intercrops, the straw pea was not capable of significantly increasing the $\mathrm{N}$ content of the mixture compared to that of the respective cereal sole crop due to the low pea proportion in the mixture. Additive intercrop (i.e., W100P50) $=100 \%$ of the sole crop density for the cereal and $50 \%$ of sole crop density for the legume. Replacement intercrop (i.e., W50P50) $=50 \%$ of the sole crop density for each crop. Values are the mean $(n=3)$. For each column, different letters (LSD) indicate significant differences among treatments $(P \leq 0.05)$. Pea sole crop was not included in the statistical analysis $W$ wheat, $B$ barley, $O$ oat, $T$ triticale, $P$ pea, $P e a_{I C}$ pea straw proportion (\%) in intercrop, $S E$ standard error

If in other studies the biomass $\mathrm{N}$ content of cereal-legume intercrops was always significantly higher than that of the corresponding cereal sole crops (Lithourgidis et al. 2006, 2011b; Sadeghpour et al. 2013), these findings were not always observed in the present study for the straw mixture $\mathrm{N}$ content. In 2006/2007, the straw mixture N content of additive intercrops with wheat and barley did not significantly differ from the corresponding cereal sole crops. The same result was found in 2007/2008 in the additive design for triticale-pea and in both additive and replacement design for oat-pea intercrops. These results indicate that in some intercrop treatments, the proportion of pea straw in the mixture was not capable of significantly increasing the $\mathrm{N}$ content of the mixture compared to that of the corresponding cereal sole crop with no $\mathrm{N}$ benefits in the fermentation process of bioethanol production.

$\mathrm{Ta}$ and Faris (1987) reported that the biomass $\mathrm{N}$ content of timothy grass (Phleum pratense) intercropped with alfalfa (Medicago sativa) was higher than in the respective sole crop. Chu et al. (2004) found higher $\mathrm{N}$ content in rice (Oryza sativa) biomass intercropped with peanut (Arachis hypogaea L.) than in rice sole crop. In our research, we analyzed separately the straw $\mathrm{N}$ content of the two intercrop components (data not shown), and in line with the above studies, we observed that, in some treatments, the cereal grown in intercrop showed a higher straw $\mathrm{N}$ content compared to that of the same cereal grown in sole crop. Due to its faster and deeper root growth and its higher $\mathrm{N}$ demand than those of pea, the cereal is more competitive for mineral $\mathrm{N}$ soil forcing the intercropped legume to fix more $\mathrm{N}_{2}$ compared to the sole legume (Bedoussac and Justes 2010). In our experiment, more mineral soil $\mathrm{N}$ might have been available for the cereal in intercrop compared to the sole cereal at full density. A higher straw $\mathrm{N}$ content of the intercropped cereal can contribute, together with the presence of the pea straw, to the overall increment of the $\mathrm{N}$ content in the straw mixture.

Cereal and pea sole crops had a similar cellulose content in $2006 / 2007$, whereas in $2007 / 2008$, it was slightly lower in pea $(-11 \%)$. The average cellulose content of the straw mixture differed significantly $(P \leq 0.001)$ between the two growing season (40.01\% in 2006/2007 and $38.40 \%$ in 2007/2008). We never observed, however, significant differences between the intercrops and their corresponding cereal sole crops.

The hemicellulose content of the cereal straw was double, on average, that of the pea straw in both cropping seasons. Such a difference may lower the hemicellulose content of the straw mixture for intercrop. Had this been the case in our study, as the proportion of pea in the straw mixture increased, the hemicellulose content would decrease. Differences between the two crop seasons in the average hemicellulose content of the mixture were not significant (25.49 and $24.74 \%$ respectively in 2006/2007 and 2007/2008). In 2006/2007, barley and oat intercrops in both designs showed a significantly 
lower hemicellulose content than their respective cereal sole crops. In 2007/2008, this was observed in barley-pea intercrops and in T50P50.

Pea had a higher lignin content than all cereals in $2006 / 2007$, while in 2007/2008, lignin content in pea was similar to triticale and wheat but higher than barley and oat. The average lignin content of the straw mixture was 6.21 and $5.34 \%$ respectively in $2006 / 2007$ and $2007 / 2008$. In 2006/2007, only O50P50 and, in 2007/2008, W100P50, O100P50, O50P50, and T50P50 showed a significantly higher lignin content than their respective cereal sole crop.

A lower content of cellulose and hemicellulose of the intercrop straw mixture compared to that of cereal sole crops straw would lower the ethanol yields, while a higher content of lignin would increase the technical issues related to the presence of this polymer in the fermentation media. Our results showed that due to the small differences between cereal and pea in the straw cellulose content, it is unlikely that the legume would considerably decrease the overall cellulose content of the mixture. In contrast, pea straw may reduce the hemicellulose content of the mixture although, in this study, we could not identify a clear relationship between the hemicellulose content of the straw mixture and its pea proportion. Regarding the lignin content of the straw mixture, ANOVA indicated a marked effect of the year $(P \leq 0.001)$, highly significant differences between treatments $(P \leq 0.001)$, and a significant interaction year $\times$ treatments $(P \leq 0.05)$. From these results, it is difficult to predict the effect of the pea straw on the lignin content of the straw mixture.

\section{Conclusion}

Cereal-legume intercropping systems are a research topic mostly studied in tropical, temperate, and semiarid environments. In our study, we focused on the specific situation where tall cereal cultivars are intercropped with legumes in a semiarid environment of the Mediterranean basin, and the harvested straw mixture is used for second-generation bioethanol production.

Our results indicated that the high height of cereal plants in intercrop may lead to a great aggressivity and suppress the biomass yields of the legume. This can reduce the advantages of the intercrop versus the sole crop system (i.e., LER, residual $\mathrm{N}$ in the soil). Furthermore, a low proportion of the legume in the intercrop straw mixture may not be appropriate to bring any benefit to the biofuel manufacturing process. In this study, tall cereal cultivars were considered a key aspect for the development of a sustainable bioethanol industry since the extra production of straw can be left to the soil to preserve its fertility. High priority should therefore be given to the identification/selection of legume cultivars capable of competing with the aggressivity of tall cereals in semiarid environments. In our study, pea performed better in the replacement than in the additive intercrop. Hence, further work should examine intercrop designs that can mitigate the aggressivity of the cereal and can guarantee a suitable proportion of pea straw in the mixture. Moreover, a characterization of the different forms of $\mathrm{N}$ contained in the straw of different legumes could provide valuable insight for the improvement of the fermentation process. Not all amino acids have the same effect on the growth and activity of yeasts, and some can actually have an inhibitory effect (Thomas and Ingledew 1990). Finally, our findings showed a strong effect of the year on the productivity of tall cereal cultivars that was strictly linked with the water availability during the crop growing season. We believe that this aspect needs further investigation in semiarid and rain-fed areas like Southern Europe where the water stress often becomes a main limiting factor on yields.

\section{References}

Agegnehu G, Ghizaw A, Sinebo W (2006) Yield performance and landuse efficiency of barley and faba bean mixed cropping in Ethiopian highlands. Eur J Agron 25:202-207. doi:10.1016/j.eja.2006.05.002

Agegnehu G, Ghizaw A, Sinebo W (2008) Yield potential and land-use efficiency of wheat and faba bean mixed intercropping. Agron Sustain Dev 28:257-263. doi:10.1051/agro:2008012

Banik P, Midya A, Sarkar BK, Ghose SS (2006) Wheat and chickpea intercropping systems in an additive series experiment: advantages and weed smothering. Eur J Agron 24:325-332. doi:10.1016/j.eja. 2005.10.010

Bedoussac L, Justes E (2010) The efficiency of a durum wheat-winter pea intercrop to improve yield and wheat grain protein concentration depends on N availability during early growth. Plant Soil 330:19 35. doi:10.1007/s11104-009-0082-2

Blanco-Canqui H, Lal R (2009) Crop residue removal impacts on soil productivity and environmental quality. Crit Rev Plant Sci 28(3): 139-163. doi:10.1080/07352680902776507

Chu GX, Shen QR, Cao JL (2004) Nitrogen fixation and N transfer from peanuts to rice cultivated in anaerobic soil in an intercropping system and its effect on soil N fertility. Plant Soil 263:17-27. doi:10. 1023/B:PLSO.0000047722.49160.9e

Corre-Hellou G, Dibet A, Hauggaard-Nielsen H, Crozat Y, Gooding M, Ambus P, Dahlmann C, Von Fragstein P, Pristeri A, Monti M, Jensen ES (2011) The competitive ability of pea-barley intercrops against weeds and the interactions with crop productivity and soil $\mathrm{N}$ availability. Field Crop Res 122:264-272

De Wit CT, Van den Bergh JP (1965) Competition between herbage plants. Neth J Agric Sci 13:212-221

Faaij A (2010) A roadmap for biofuels [Editorial]. Biomass Bioenerg 34: 157-158. doi:10.1016/j.biombioe.2009.10.007

Fujita K, Ofosubudu KG, Ogata S (1992) Biological nitrogen fixation in mixed legume-cereal cropping systems. Plant Soil 141:155-175

Goering HK, Van Soest PJ (1970) Forage fiber analysis: apparatus reagents, procedures, and some applications. Agric Handbook 379. U.S. Government Printing Office, Washington

Gooding MJ, Kasyanova E, Ruske R, Hauggaard-Nielsen H, Jensen ES, Dahlmann C, Von Fragstein P, Dibet A, Corre-Hellou G, Crozat Y, Pristeri A, Romeo M, Monti M, Launay M (2007) Intercropping 
with pulses to concentrate nitrogen and sulphur in wheat. J Agric Sci 145:469-479. doi:10.1017/S0021859607007241

Hauggaard-Nielsen H, Jensen ES (2001) Evaluating pea and barley cultivars for complementarity in intercropping at different levels of soil $\mathrm{N}$ availability. Field Crop Res 72:185-196

Hauggaard-Nielsen H, Ambus P, Jensen ES (2003) The comparison of nitrogen use and leaching in sole cropped versus intercropped pea and barley. Nutr Cycl Agroecosyst 65:289-300

Hauggaard-Nielsen H, Andersen MK, Jørnsgaard B, Jensen ES (2006) Density and relative frequency effects on competitive interactions and resource use in pea-barley intercrops. Field Crop Res 95:256267. doi:10.1016/j.fcr.2005.03.003

Hill J (2007) Environmental costs and benefits of transportation biofuel production from food- and lignocellulose-based energy crops. A review. Agron Sustain Dev 27:1-12. doi:10.1051/agro:2007006

Lithourgidis AS, Vasilakoglou IB, Dhima KV, Dordas CA, Yiakoulaki $\mathrm{MD}$ (2006) Forage yield and quality of common vetch mixtures with oat and triticale in two seeding ratios. Field Crop Res 99:106-113. doi:10.1016/j.fcr.2006.03.008

Lithourgidis AS, Dordas CA, Damalas CA, Vlachostergios DN (2011a) Annual intercrops: an alternative pathway for sustainable agriculture. Aust J Crop Sci 5(4):396-410

Lithourgidis AS, Vlachostergios DN, Dordas CA, Damalas CA (2011b) Dry matter yield, nitrogen content, and competition in pea-cereal intercropping systems. Eur J Agron 34:287-294. doi:10.1016/j.eja. 2011.02.007

Liu Y, Wu L, Baddeley JA, Watson CA (2011) Models of biological nitrogen fixation of legumes. A review. Agron Sustain Dev 31(1): 155-172. doi:10.1051/agro/2010008

McGilchrist CA, Trenbath BR (1971) A revised analysis of plant competition experiments. Biometrics 27:659-671

Neumann A, Werner J, Rauber R (2009) Evaluation of yield-density relationships and optimization of intercrop compositions of fieldgrown pea-oat intercrops using the replacement series and the response surface design. Field Crop Res 114:286-294. doi:10.1016/j. fcr.2009.08.013

Petersson A, Thomsen MH, Hauggaard-Nielsen H, Thomsen AB (2007) Potential bioethanol and biogas production using lignocellulosic biomass from winter rye, oilseed rape and faba bean. Biomass Bioenerg 31:812-819. doi:10.1016/j.biombioe.2007.06.001

Pristeri A, Dahlmann C, Von Fragstein P, Gooding MJ, HauggaardNielsen H, Kasyanova E, Monti M (2006) Yield performance of faba bean-wheat intercropping on spring and winter sowing in European organic farming systems. In: Andreasen CB, Elsgaard L, Sørensen LS, Hansen G (eds) Proceedings of the European Joint Organic Congress: Organic Farming and European Rural Development, Odense (DK), 30-31 May 2006. Danish Research Centre for Organic Food and Farming (DARCOF), Tjele, pp 294 295

Rauber R, Schmidtke K, Kimpel-Freund H (2001) The performance of pea (Pisum sativum L.) and its role in determining yield advantages in mixed stands of pea and oat (Avena sativa L.). J Agron Crop Sci 187:137-144

Reddy BVS, Sanjana Reddy P, Bidingera F, Blümmel M (2003) Crop management factors influencing yield and quality of crop residues. Field Crop Res 84:57-77. doi:10.1016/S0378-4290(03)00141-2

Sadeghpour A, Jahanzad E, Esmaeili A, Hosseini MB, Hashemi M (2013) Forage yield, quality and economic benefit of intercropped barley and annual medic in semi-arid conditions: additive series. Field Crop Res 148:43-48. doi:10.1016/j.fcr.2013.03.021

Sims REH, Mabee W, Saddler JN, Taylor M (2010) An overview of second generation biofuel technologies. Bioresource Technol 10: 1570-1580. doi:10.1016/j.biortech.2009.11.046

Ta TC, Faris MA (1987) Species variation in the fixation and transfer of nitrogen from legumes to associated grasses. Plant Soil 98(2):265274

Thomas KC, Ingledew WM (1990) Fuel alcohol production: effects of free amino nitrogen on fermentation of very-high-gravity wheat mashes. Appl Environ Microbiol 56(7):2046-2050

Thomsen MH, Hauggaard-Nielsen H (2008) Sustainable bioethanol production combining biorefinery principles using combined raw materials from wheat undersown with clover-grass. J Ind Microbiol Biotechnol 35(5):303-311. doi:10.1007/s10295-008-0334-9

Vandermeer J (1989) The ecology of intercropping. Cambridge University Press, Cambridge 